\title{
On the Licensing System in Kyrgyz Customary Law: Historical and Legal Aspects
}

\section{Zhyldyz Dekhanova1, Bakyt Alikulov', Gulsara Kuldysheva1, Feruza Tanatarova1, Gulizat Arstanbaeva1, Aigul Mirzaeva², Zhypargul Abdullaeva ${ }^{3 *}$}

\author{
${ }^{1}$ Department of Theory and History of Government Law, Osh State University, Osh, Kyrgyzstan \\ ${ }^{2}$ Department of Criminal Law and Procedure, Osh State University, Osh, Kyrgyzstan \\ ${ }^{3}$ Science and Research Department, Osh State University, Osh, Kyrgyzstan \\ Email: *jypar.science@oshsu.kg
}

How to cite this paper: Dekhanova, Z., Alikulov, B., Kuldysheva, G., Tanatarova, F., Arstanbaeva, G., Mirzaeva, A., \& Abdullaeva, Z. (2022). On the Licensing System in Kyrgyz Customary Law: Historical and Legal Aspects. Open Journal of Social Sciences, 10, 193-198.

https://doi.org/10.4236/jss.2022.101017

Received: November 22, 2021

Accepted: January 17, 2022

Published: January 20, 2022

Copyright (c) 2022 by author(s) and Scientific Research Publishing Inc. This work is licensed under the Creative Commons Attribution International License (CC BY 4.0).

http://creativecommons.org/licenses/by/4.0/

\begin{abstract}
This article is investigating licensing system in Kyrgyz customary law based on its historical and legal aspects. Research purpose is to establish creative comprehension from Kyrgyz customary law experience and its practical application considered as a source for further growth and improvement. In this regard, the study of internal affair members' history in Kyrgyzstan acquires great cognitive and educational values. Research methods and materials are based on historical-comparative, analysis of historical facts and scientific publications describing legal aspects. Research results showed Kyrgyz people's behavior to use of weapons from nomadic to recent times.
\end{abstract}

\section{Keywords}

Component, Licensing System, Kyrgyz Customary Law, Historical and Legal Aspects

\section{Introduction}

Permissive system was established from $17^{\text {th }}$ to $18^{\text {th }}$ centuries during the period of prosperity of absolute monarchies in the territories of Western Europe and Tsarist Russia. During this period, the monarchical power carried out a number of control functions, such as strict police supervision over government subjects and in their life's detailed regulation. These governments' citizens had right to travel to another country, open workshops or factories based on issued permits (Minbaev \& Kuldysheva, 2019).

Restrictions on rights regarding freedom of movement, such as entry, exit and movement within a specific territory, are a poisonous point in the history of the 
origin and development of the permitting system of Western European states (Emanuele \& Chiaramonte, 2019) and Russia during the monarchy (Fedorova-Kuznetsova, 2019).

Subsequently, issue of such permits was entrusted mainly to the police structures or internal affairs bodies. From this kind of "permits", as a result of progressive innovations in the field under study, all other "permits" appeared in the legal field, in particular, patent and license, due to their specificity and purpose, associated directly with economic activities.

The history of weapons appearance is directly related to a certain stage in the development of mankind. This reflects improvement of human knowledge and development of new technologies, as well as artificial intelligence (Proydakov, 2018). In this regard, it can be said that weapons have always been relevant to humans.

Referring to the Kyrgyz people's history, scholars note that: "The constant threat of an external attack, frequent tribal clashes forced the Kyrgyz to be always ready for military action. They were not only tireless riders, but also brave warriors who skillfully wielded weapons".

In general, Kyrgyz people combatting weapons are subdivided into following types:

1) Offensive weapons which are designed to defeat enemy in close and hand-to-hand combat: swords, broadswords, spears, aybalta (battle ax);

2) Offensive weapons of distance combat to defeat enemy at a distance: bow and arrows, i.e. throwing weapons;

3) Protective weapons designed to protect warrior from defeat in battle: shield, armor to protect warrior arms, legs, chest, head and body (Khudyakov, 1980).

It can be noted that in United States, citizens have been allowed to keep and carry weapons for a long time. In Article 2 (US Constitution, 1787) "Bill about Rights", which is currently in force, it was stated: “...since a well-organized militia is necessary for the security of a free state, the right of the people to keep and bear arms should not be violated".

In Western European countries, rather strict requirements were established that obliged manufacturers or purchasers of weapons to obtain a special permit from the police (Kupren \& Hakuć-Błażowska, 2021).

Russian legislation throughout its development has attempted to create effective arms control (Hung, 2015). A document such as the "Deanery harter" (Police Charter of 1782) allowed the carrying of weapons only to those persons who were "allowed and prescribed" (Russian Reforms History Museum Named after P.A. Stolypin, 2013).

Later legislative acts of pre-revolutionary Russia also regulated the rules for handling weapons. Thus, the Code on Punishments in the 1885 edition of Section No. 8 provided for criminal liability for "the illegal manufacture and storage of weapons or gunpowder to protect the personal safety of the established rules of caution" (Code of Russian Empire Laws, 1885). 
In the nomadic Kyrgyz society, special attention was paid to weapons, since a person with his own weapon was considered an equal member of such. According to the norms of the customary law of the Kyrgyz, items that were necessary for hunting, as well as military equipment, were subject to increased protection. Kyrgyz Customary law influence application and implementation of recently reformed legal rules on the land rights, dispute solutions, and influences on villagers' value in the written law (Giovarelli \& Akmatova, 2002). Customary law norms and customs formed during a long historical, centuries-old period when established rules of people's behavior could be repeatedly transferred (Mukambaeva, 2004). Kyrgyz customary law study provides an opportunity to show the evolution of legal system in Kyrgyzstan (Kuldysheva et al., 2021).

In this article, research methods and materials are based on the historical-comparative method analyzing information by comparing historical and legal sources (Shigal, 2013); formal logical methods gaining information based on historical facts (Egorova, 2015) and scientific publications analysis describing legal aspects in Kyrgyz customary law.

\section{Rules in Nomadic Society}

In a nomadic society, both Kazakhs and Kyrgyz, there were a number of strictly observed rules aimed at regulating the handling of weapons transmitted from generation to generation in the form of artistic words, proverbs, sayings, aphorisms, prohibitions and signs. Then they gradually began to take on a documentary form: “...so that no Kyrgyz should appear in people's meetings except with weapons."

Kyrgyz clans and tribes followed "adat" rule establishments started from the depth of centuries, formed by Kyrgyz people as a legal system in the period of early feudalism (Brenner, 1990). Later, when Kyrgyz traditional society began to decompose, the norms of the adat gradually adapted to the interests of the feudal nobility, represented by both the manaps and the biys. Weapons similar to arrows were discovered as a part of weapon complexes belonging to nomadic ancient and medieval ethnicities inhabiting the Central Asian historical cultural region (Khudyakov \& Borisenko, 2018).

The unarmed man had no voice, and the younger ones could not give way to him. So that everyone who can bear arms (except for sultans) would pay one twentieth of their property to khan and the rulers annually. Every generation, clan and division should have their own "tamga" (symbols or letters). "These tamga letters were distributed at the same time, with the obligation to put them on all livestock and property, to distinguish what belongs to whom" (Kulteleev et al., 1998).

It should be noted that uncontrolled use of weapons was suppressed in Kyrgyz society. Thus, "the common law of the Kyrgyz contained a number of norms that took into account aggravating and mitigating circumstances. Aggravating circumstances include committing a crime with weapons use" (Kozhonaliev, 2000). 
For example, in "erezhe" from 1893, the following was indicated: "If a thief inflicted wounds, the punishment for them is especially imposed, and for theft is increased." On this occasion, N.I. Grodekov noted: “Among the Kara-Kirghiz, those who caught the thief tie him up, then subject him to corporal punishment (jabr kursetet), until the case is analyzed by a biy. Without denying the injustice of the punishment before the decision of the case by a biy, Kunakbai (biy of the Talas valley of the Aule-Ata district) justifies this custom for those cases when a thief is caught red-handed or was armed with a spear or an ax (aibalta)" (Kozhonaliev, 2000).

The punishment for crime commission by a person with use of a weapon was harsher than otherwise. The responsibility for committing theft was increased if it was carried out with any weapon use. In cases where such a crime was accompanied by infliction of beatings or wounds on someone, the responsibility was doubly toughened.

It is a historical fact that disputes and conflict situations were resolved with a cold steel weapon. For example, if the close relatives of killer did not want the offender to be executed, they first of all attempted to pay a fine (kuna) to injured party, and if the parties did not come to a mutual agreement, then the matter was resolved on both sides by a duel. Chosen persons from both disputing parties went out to a duel with melee weapons, which as a result ended by ones death.

According to the customary law of the Kyrgyz, "attempted murder is punished in the amount of 1 to 3 toguz in the form of 'bychak ayby' (purnishment for knife use)" (Kozhonaliev, 2000).

\section{Actions from Epic "Manas"}

The greatest oral folk art work "Manas" is a life encyclopedia of Kyrgyz people. In this source, it is possible to find a rich vocabulary related to weapons (Khudyakov \& Borisenko, 2015). So, "the names of firearms are presented in epic with rich terminology", rich terminology is associated with a bow, arrows, quivers and its other details, ...in the lines of "Manas" many names of swords and sabers were mentioned, the Epic "Manas" contains more than twenty names belonging to Kyrgyz soldiers protective combat clothing (Kozhonaliev, 2000). Warrior courage during the battle with enemies was characterized at the level how he skillfully can use weapons which are mainly considered by weapons made from iron (Yusupova, 2018).

Almost everyone who could hold a weapon in his hands was endowed with right to hunt by any means anywhere. In this case, understanding remains by people of that time that it was not allowed to hunt everywhere, but allowed only in certain places.

When the place chosen by hunter for setting the traps was at a distance from the village that shepherds usually go for a cattle, in this case the hunter was liable commensurate with consequences. Then, if a person does not violate the established rules, then he does not bear any responsibility. 
Talyzin (1898) writes about Kyrgyz weapons: "Some manaps still keep, as an honorable memory of previous military exploits, full weapons, consisting of a helmet, chain mail, knee pads, saber, spear, bow, quiver with arrows, etc.”. This information testifies to the reverent attitude of the Kyrgyz towards weapons (Kulteleev et al., 1998).

The procedure for carrying weapons was especially stipulated: "entering the quarters with any weapon is only proper for enemy and therefore bringing it into a peaceful dwelling of a Kyrgyz by a completely peaceful traveler is again prohibited. A weapon, if anyone has one, should be left behind the quarters, leaning against its riffle (the front of the quarters is immediately on both sides of its entrance). The customs looked even stricter on the close approach to khan's headquarters. At the entrance to the khan there should not even be a whip in his hand. The violator of these rules, although not subject to special punishment (except for cases of violation of these in relation to the khan), but is always subjected to not quite delicate treatment with him aul, who have the right to contradict him kunak-as, a treat" (Kulteleev et al., 1998).

\section{Conclusion}

The above indicates the presence of a huge number of rules governing the procedure for handling weapons, which undoubtedly was widespread in the nomadic society of both Kazakh and Kyrgyz people. Kyrgyz customs and traditions value is characterized by considering the nomadic tribe associations in historical development course. It was found that elements from weapon complexes belonging to nomadic ancient and medieval ethnicities inhabited the Central Asian historical-cultural region. Therefore, ancient Kyrgyz people were able to master ways of weapons procurement from metals. Thus, references about weapons can be found in various documents that have come down to our time regulating issues of murder, punishment, hunting or public peace and safety, etc.

\section{Conflicts of Interest}

The authors declare no conflicts of interest regarding the publication of this paper.

\section{References}

Brenner, R. (1990). Feudalism. In J. Eatwell, M. Milgate, \& P. Newman (Eds.), Marxian Economics. The New Palgrave (pp. 170-185). Palgrave Macmillan.

https://doi.org/10.1007/978-1-349-20572-1_25

Code of Russian Empire Laws (1885). Vol. 15, Section 8, 500 p. http://pravo.gov.ru/proxy/ips/?empire

Egorova, O. A. (2015). Function of Logical Methods and Means in the Methodology of Legal Knowledge. Bulletin of the South Ural State University, Series: Pravo, 15, 7-14. https://doi.org/10.14529/law150401

Emanuele, V., \& Chiaramonte, A. (2019). Explaining the Impact of New Parties in the Western European Party Systems. Journal of Elections, Public Opinion and Parties, 29, 
490-510. https://doi.org/10.1080/17457289.2019.1666402

Fedorova-Kuznetsova, I. V. (2019). Monarchical System of Power in the Modern World and Its Features. Society: Politics, Economics, Law, 9, 35-38.

Giovarelli, R., \& Akmatova, C. (2002). Local Institutions that Enforce Customary Law in the Kyrgyz Republic and Their Impact on Women's Rights. Agriculture \& Rural Development e-Paper, World Bank.

Hung, A. Z. (2015). Problems of Legal Regulation of Necessary Defense in the Activities of the Police. Bulletin of Krasnodar University of the Ministry of Internal Affairs of Russia, 4, 84-87.

Khudyakov, Y. (1980). Weaponry of the Yenisei Kyrgyz VI-XII Centuries. Novosibirsk, $176 \mathrm{p}$.

Khudyakov, Y. S., \& Borisenko, A. Y. (2015). Iron Clubs from the Chui and Talas Valleys of Kyrgyzstan (From the Collections of the Manas-Ordo and Rarity Museums). Novosibirsk State University Bulletin. Series: History. Philology, 14, 76-82.

Khudyakov, Y. S., \& Borisenko, A. Y. (2018). Collection of Iron Arrowheads from the Era of the Kyrgyz Great Power from the Kyrgyz National Museum in Bishkek. Novosibirsk State University Bulletin, Series: History, Philology, 17, 99-106. https://doi.org/10.25205/1818-7919-2018-17-7-99-106

Kozhonaliev, S. K. (2000). Common Law of the Kyrgyz (p. 32). Bishkek.

Kuldysheva, G., Minbaev, S., Paraidinuulu, S., Mirzaeva, A., Atantaev, A., Rustam, M., Amanbek, K., Abdullaeva, Z., \& Toktobaeva, E. (2021). Kyrgyz Customary Law Development. Open Journal of Social Sciences, 9, 321-327. https://doi.org/10.4236/jss.2021.91023

Kulteleev, T. M., Masevich, M. G., \& Shakaev, G. B. (1998). Materials on Kazakh Customary Law: Popular Scientific Edition (464 p.). Kazakhstan Republic Academy of Sciences, Almaty.

Kupren, K., \& Hakuć-Błażowska, A. (2021). Profile of a Modern Hunter and the Socio-Economic Significance of Hunting in Poland as Compared to European Data. Land, 10, Article No. 1178. https://doi.org/10.3390/land10111178

Minbaev, S. A., \& Kuldysheva, G. K. (2019). On the Licensing System in the Common Law of the Kyrgyz. Domestic Jurisprudence, 2, 5-8.

Mukambaeva, G. A. (2004). Manas and Law(226 p). Bishkek.

Proydakov, E. M. (2018). The Current State of Artificial Intelligence. Research in Science, 129-153. https://doi.org/10.31249/scis/2018.00.09

Russian Reforms History Museum Named after P.A. Stolypin (2013). Charter of the Deanery or Policeman 1782. http://museumreforms.ru/node/13635

Shigal, D. A. (2013). The Theory of the Historical and Legal Comparative Method. Legality Problems, 124, 1-8.

Talyzin, A. (1898). Pishpek District. Historical Sketch 1855-1868 (464 p.). Semirechensk Regional Statistical Committee.

US Constitution (1787). Bill about Rights 1791. https://sites.google.com/site/otvetyigpzs/-period-novogo-i-novejsego-vremeni/konstitu cia-ssa-1787-g-bill-o-pravah-1791-g

Yusupova, R. O. (2018). Ethnometallurgical Philosophy in the Epic "Manas". International Journal of Humanities and Natural Sciences, 5, 46-50. 